DOI https://doi.org/10.36059/978-966-397-159-9/69-88

\title{
ADMINISTRATIVE AND LEGAL REGULATION PECULIARITIES OF THE MANAGING ACTIVITIES OF THE UKRAINIAN STATE BORDER GUARD BODIES (UNITS) CHIEFS
}

\section{Vadym Polovnikov}

\section{INTRODUCTION}

In the context of administrative reform, optimization of the system of central executive bodies, other structural and political transformations in Ukraine, the issues of improvement of administrative and legal regulation of public administration and, directly, management in such specific field as safeguarding and protection of state border of Ukraine (hereinafter - SBU) are acute. The current state of managing activities in this area needs improvement. The content of managing activities of the state border guard bodies (units) chiefs of the State Border Guard Service of Ukraine (hereinafter - SBGSU) changes significantly in the modern conditions, has certain peculiarities and its qualitative implementation is not possible without proper administrative and legal regulation. Accordingly, these issues are extremely relevant today.

The scientific and theoretical basis for this work's writing was made by scientific works of such domestic and foreign scientists as: L.M. Albastova, G.V. Atamanchuk, E.M. Babosov, Y.P. Bytyak, E.B. Dorin, V.V. Zalozh, V.V. Zui, V.G. Ignatov, A.P. Kamyshnikov, S.V. Karpenko, S.M. Knyazev, L.V. Koval, A.M. Kolodiy, V.K. Kolpakov, A. T. Komziuk, V. V. Kopeychikov, A. G. Korchenko, B. M. Lazarev, S. L. Lysenkov, V. A. Lipkan, M. M. Litvin, V. Y. Malinovsky, V.I. Makhinin, M.I. Melnyk, V.M. Priymak, V.E. Sevryugin, O.F.Skakun, V.P. Sladkevich, M.I. Khavroniuk, A.D. Cherniavskiy, Y.S. Shemshuchenko, A.S. Shcherbakov, and others.

\section{General characteristics of the administrative} and legal regulation peculiarities of the managing activities of the Ukrainian state border guard bodies (units) chiefs

Characterizing the peculiarities of administrative and legal regulation of the managing activities of the state border guard bodies (units) chiefs of the SBGSU, we proceed from the fact that the principle of the rule of law is recognized in Ukraine. Ukraine's Constitution has the highest legal force. 
Laws and other legal acts are adopted based on Ukraine's Constitution and must comply with it. Ukraine's Constitution norms are direct action norms (Article 8 of the Constitution of Ukraine) ${ }^{1}$.

Ukraine's Constitutional court in its decisions has repeatedly noted that according to Article 19 of Ukraine's Constitution, all public authorities are obliged to act only on the basis and within the powers and in the manner provided by Ukraine's laws and Constitution. Decision of June 17, 2010 No. 17-rp / 2010 stated that "one of the rules of law's elements is the principle of legal certainty, which states that fundamental human rights' restriction and the implementation of these restrictions in practice are permissible only in case of ensuring of predictability of legal norms' application, established by such restrictions. That is, any right's restriction must be based on criteria which enable a person to separate lawful behavior from unlawful one, to foresee this conduct's legal consequences" (paragraph 3, subparagraph 3.1, motivation part article 3$)^{2}$.

The same Decision refers to another Decision of Ukraine's Constitutional court No. 5-rp / 2005 dated September 22, 2005, which states that legal rule's requirements of certainty, clarity, and ambiguity follows from the constitutional principles of equality and justice, since otherwise cannot provide it the same application, does not exclude the unrestricted interpretation in law enforcement practice and inevitably leads to arbitrariness (paragraph 5, subparagraph, 5.4, motivation part article 5) ${ }^{3}$. This directly applies to the administrative and legal regulation of internal and external managing activities of the SBGSU state border guard bodies (units) chiefs.

Considering this issue, it should be emphasized that administrative and legal regulation is considered as one of the managing methods.

According to the Legal Encyclopedia, the method of legal regulation is a way of legal norms influencing public relations. It is characterized by the following features: applies only to legal provisions; ensures the unity of legal regulation; is guaranteed in cases of necessity utilizing state coercion; is one of the criteria for the division of law in the branches. Legal regulation methods are divided into imperative and dispositive. The imperative method implies an overbearing influence on the members of public relations without

\footnotetext{
${ }^{1}$ Konstitutsia Ukrayini: zakon Ukrayini № 254к/96-VR [Constitution of Ukraine]. 28 June 1996. Data onovlennia: 21.02.2019. URL: https://zakon2.rada.gov.ua/laws/main/254к/96-вр (date of request: 31.10.2019). [In Ukrainian]

${ }^{2}$ Rishenniya Konstitutsiynogo sudu Ukrainy №. 17-rp / 2010 [Judgment of the Constitutional Court of Ukraine]. 29 June 2010. URL: https://zakon.rada.gov.ua/laws/show/ v017p710-10 (date of request: 31.10.2019). [In Ukrainian]

${ }^{3}$ Rishenniya Konstitutsiynogo sudu Ukrainy №. 17-rp / 2010 [Judgment of the Constitutional Court of Ukraine]. 29 June 2010. URL: https://zakon.rada.gov.ua/laws/show/ v017p710-10 (date of request: 31.10.2019). [In Ukrainian]
} 
the right to choose (e.g., in criminal and administrative law). The dispositive method, on the contrary, provides options of behavior of public relations participants as equal parties (it is applied, in particular, in civil law). There are also other classifications of legal regulation methods in the legal literature: general permits and special permits; subordination and coordination; education, encouragement, and coercion. This testifies to the complex nature of this legal category, which often appears not in its pure form, but as a set of methods of law rules implementing ${ }^{4}$.

According to E.M. Babosov, following the classical tradition, which originates in the writings of M. Weber, there are relations of dependence, power, submission, and domination, which are decisive in the management system. Since between $50 \%$ and $90 \%$ of their working time, people involved in management spend on communication with their subordinates or chiefs, it is important to find appropriate models and methods of communication, thanks to which you can develop and implement optimal solutions, namely those that at the same time and in the best way ensure the achievement of two different goal groups, oriented by the actions of two different, quite often social rivals - individuals, society and the state ${ }^{5}$.

Ukraine's state border guard bodies (units) are included in the SBGSU system, which is known to be a complex, multilevel and integrated dynamically developing system. The management ensures its preservation and further development, streamlining its structure, interaction with other state bodies, public organizations, population and activities' purpose (goals) achievement.

According to the Interpretative Dictionaries of the modern Ukrainian language, management - action with meaning "to manage" means: 1. To direct the activity, the work of someone, something; to lead someone, something; to guide. 2. To direct the course, the course of a process, to influence the development, the state of something ${ }^{6,7}$. The content of management as a social function is manifested in the organizing activity, which is achieved through unification, adjustment, regulation, coordination,

\footnotetext{
${ }^{4}$ Yuridichna Ensiklopediya [Legal Encyclopedia] / red. Y.S.Shemshuchenko [ta insh.] / NAN Ukrainy, V.M. Koretsky Institut derzavi i prava. Kyiv: vid. Ukrainska entsiklopediya im.M.P. Bazhan, Toml. 3: K-M. 2001. P. 617. [In Ukrainian]

${ }^{5}$ Babosov, E. M. Sotsyolohyya upravleniya : posobye dlya studentov vuzov [Sociology of management] / E. M. Babosov. 6-e izd., pererab. y dop. Mynsk : TetraSystems, 2010. S. 3-4.[In Ukrainian]

${ }^{6}$ Velykyy tlumachniy slovnyk suchasnoyi ukrayins'koyi movy [The Big Interpretive Dictionary of Modern Ukrainian] / Uklad. i holov. red. V. T. Busel. Kyiv; Irpin': VTF «Perun», 2009. S. 1511. [In Ukrainian]

${ }^{7}$ Noviy tlumachniy slovnyk ukrayins'koyi movy : u 3 t. 200000 sliv [New interpretative dictionary of the Ukrainian language] / [uklad. Vasyl' Yaremenko, Oksana Slipushko]. vyd. 2-e, vypr., t. 3 P-YA. Kyiv : AKONIT, 2008. S. 624-625. [In Ukrainian]
} 
and control. The organizing function of social management is inextricably linked to power-organizing activity. There is no society as a complex selfgoverning system without management, as there is no social management without the will, power, and authority. The government acts as a functional property, social organization immanent quality, which is realized through social management, should be carried out based on the subordination and unity of will of joint activity participants. In this context, management is primarily a state's organizing activity, the main feature of which is power. This type of management is called public administration. Only public administration ensures the functioning and development of society as a whole ${ }^{8}$.

Legal regulation in the theory of law refers to the state's specific activity, its bodies, and officials on the regulation of social relations by establishing legal norms and making, in the necessary cases, individually-regulatory decisions following these norms on legally significant issues arising in the process of such relations. Legal regulation is functional, managerial.

Administrative and legal regulation of Ukrainian state border guard bodies (units) chiefs' managing activities is a consolidation at the level of legal acts that proclaim legal norms, management procedures. Such regulation is at Ukraine's laws and by-laws level.

Classification according to the constituent entities is a common differentiation of legal acts. Thus, the Verkhovna Rada of Ukraine, according to Ukraine's Constitution Art. 91, adopts laws, decrees and other acts (resolutions, declarations, appeals, statements). The President of Ukraine, according to Ukraine's Constitution Art. 106, issues decrees and orders. Ukraine's executive bodies issue the following legal acts: the Cabinet of Ministers, following Ukraine's Constitution Art. 117, - resolutions and orders; other executive bodies (departments and agencies) - orders. By external form, the main legal acts in Ukraine are the Constitution, laws, decrees, decisions, orders, etc.

Ukraine's current legislation does not define the term «legal act». In the legal and specialized literature, there is also no consensus on the attribution to the legal bases in our case of managing activities of departmental orders, instructions, and other official regulations. The author of this study is an adherent of the view that all departmental legal acts do not create legal norms in the field of management, but determine the methodology and tactics of its implementation, the mechanism, and process of management,

\footnotetext{
${ }^{8}$ Yuridichna Ensiklopediya [Legal Encyclopedia] / red. Y.S.Shemshuchenko [ta insh.] / NAN Ukrainy, V.M. Koretsky Institut derzavi i prava. Kyiv: vid. Ukrainska enciklopedia im.r M.P. Bazhan, Tom.T. 6: T-Y. 2004, pp. 218-219. [In Ukrainian]
} 
principles and other provisions that are mandatory for management. In this case, we must proceed from the requirements of the Constitution's Art. 8, which provides that the rule of law applies in Ukraine since laws and other legal acts are adopted based on the Constitution and must comply with it.

Given the above, any body's leader's management activities' administrative and legal regulations are constituted by legal acts - official documents, which are created by state's competent authorities and contain mandatory legal norms (rules of conduct). They are the result of competent entities' activities, which called law-making - activities aimed at creating, amending or repealing regulations.

Unfortunately, legislative practice and technology in Ukraine do not fully implement the principle of legal certainty in terms of detailing management activity's procedures at the level of laws and their content, as a rule, is declarative, which leads to different interpretations and understanding of these rule's contents.

Forming a general concept of legislation, taking into account the specifics of management, the legislator abandoned the detailed legal regulation of all necessary management procedures and legal relations directly at the level of legislative acts. The current legislation only includes regulations of a general nature, revealing only the basic features of individual procedures. To specify their essence and to establish clear procedural rules, the legislator envisaged the possibility of issuing relevant departmental and interagency subordinate legal acts by the Administration of the SBGSU.

Regarding the legal acts that form the basis of administrative and legal regulation (legal basis) of the managing activities of the SBGSU state border guard bodies (units) chiefs, their number is quite large. Such acts define the general and individual competence (functions, duties, and rights) of the SBGSU body's (unit's) personnel in carrying out official (including management) activity, its social and legal status, protection, responsibility, etc.

That is, the legal regulation of the SBGSU state border guard bodies (units) chiefs managing activities is constituted by legal acts that can be divided into the following groups: 1) Ukraine's Constitution and laws; 2) Ukraine's Verkhovna Rada resolutions; 3) Ukraine's President's decrees and orders; 4) Ukraine's Cabinet of Ministers' resolutions and orders; 5) Orders of the Ministry of Interior and Administration of the SBGSU, SBGSU governing bodies' orders.

Constitution of Ukraine and laws determine the general principles of management, the status of SBGSU and its credentials. Each of these laws regulates certain social relations groups that arise in the course of 
management and in connection with it, in the course of professional activity, interaction, international cooperation, control, supervision, etc. Concepts, strategies, and programs for the development of the SBGSU, its bodies (units) determine the direction of management for the future. Regulations on the bodies (units) of the SBGSU determine their legal status, credentials of these bodies' (units) chiefs. The Orders approving the Instructions (lists, procedures), determine the order of activity, specify the legal norms, establish clear rules, administrative procedures in the activities of the chiefs and other officials of the bodies (units) of the SBGSU.

According to the laws of management, any organization exists and operates through its leadership. It is the leader who develops the management strategy, consolidates the efforts of his subordinates to achieve the goals and accomplish important tasks, which, in turn, is reflected in the preparation and adoption of appropriate management decisions.

The legal encyclopedia defines a management decision as a key act of the management process, which in its essence is the order of the managing entity (management entity) to a managed object (management object) and is subject to the mandatory implementation of the latter. It is a deliberate, willful, powerful act of organizing influence, which expresses the management entity's intention to object's desired functioning, contains a certain model of its actions aimed at achieving the expected result. The management decision must be scientifically sound, timely, competent, lawful, consistent, realistic to implement ${ }^{9}$.

When executing decisions, administrative (organizational and administrative) methods are generally used in combination with other forms, means, and activity methods. The important role at this stage is played by the discipline, observance of law. The managerial activity of the leader is of particular importance in such hierarchical structures as the SBGSU, built on the principle of unity.

SBGSU body's chief should be considered an official, vested with administrative authority, entrusted with the legal acts carrying out organizational, administrative, representative and other functions (professional, control, analytical, educational), given the right to make the most important administrative decisions on all areas of activities and the application of disciplinary influence measures in order to effectively fulfill operative and service activities' (hereinafter - OSA) tasks by the subordinate.

\footnotetext{
${ }^{9}$ Yuridichna Ensiklopediya [Legal Encyclopedia] / red. Y.S.Shemshuchenko [ta insh.] / NAN Ukrainy, V.M. Koretsky Institut derzavi i prava. Kyiv: vid. Ukrainska enciklopedia im.r M.P. Bazhan, Tom.T. 6: T-Y. 2004, P. 219-220. [In Ukrainian]
} 
The chief's of the body (unit) OSA content is reduced to performing these functions and, as practice shows, the multi-purpose, multifaceted and multifunctional nature of the SBGSU activity places high demands on the level of organizational skill of the chief, which is materialized in his managerial work. Characterizing the content of his managing activities, it must be assumed that he currently bears full responsibility for the organization of services and units, logistics and human resources, compliance with the discipline and legality, etc. It is the chief of the body (unit) of the SBGSU who plays the main role in the process of external administrative and internal administrative (organizational) activity. Also, he is a military official who manages the military body (unit).

The main content of the OSA management process in the SBGSU is to carry out a direct targeted influence of the chief on the body (unit) through the appropriate mechanism. In the process of such influence, the goals, tasks, functions, principles, and methods that make up the content of the management mechanism are practically realized; performing management functions complex of methods (planning, organization, coordination, control and motivation) is used; management decision making; management of functional subsystems (personnel, resources, finances, etc.). During the OSA, the military personnel and employees of the SBGSU have organizational relations, which are reflected in vertical (subordination) and horizontal (coordination) relations.

The body's (unit's) chief of the SBGSU is a special subject of management activities, which he organizes, carries out and at the same time controls the implementation of the management process regulation instructions. The administrative and legal status of an official originates from the moment of his replacement. His position defines the range of official authority and requirements for the person's official conduct. In case of violation of legal norms by body's (unit's) chief, depending on the type and meaning of responsibility, he may be prosecuted as a criminal, administrative, disciplinary, civil and material liability. Ignorance of law's requirements does not release from liability. The officials' legal responsibility is the result of their negligent performance or failure to exercise their official credentials. Officials as holders of legal authority are a special subject of all legal responsibility types.

In accordance with the decision of the National Security and Defense Council of May 6, 2015, "On the National Security Strategy of Ukraine", the reform and development of the intelligence, counterintelligence and law enforcement agencies of Ukraine (Part 4.4) should be carried out on the rule of law basis, patriotism, competence, deportation, appropriate 
demilitarization, coordination and interaction, division of tasks and elimination of functions duplication, democratic civil control and transparency. According to the final provisions of the Strategy, it is a binding document and a basis for the development of other strategic planning documents in the field of national security - sectorial strategies, as well as state programs for the development of the security and defense sector bodies ${ }^{10}$.

Scientists and practices have repeatedly drawn attention to the specifics of the state border guard bodies' activities, and in Art. 2 of the Law of Ukraine «On State Protection of Court and Law Enforcement Employees» in 1993 these bodies were called law enforcement for the first time. This view was later supported by scientists.

Granting the SBGSU the right to use coercion as one of external administrative activities methods determines its position's peculiarities in Ukraine's system of executive bodies. It is, in fact, a «law-enforced» body ${ }^{11}$. Also, the special mission of the SBGSU as a law enforcement agency is important. The Administration of the SBGSU is the central executive body with a special status, that implements state policy in the sphere of SBU's protection, and the SBGSU - is a law enforcement agency of specialpurpose (Articles 6, 7 of the Law of Ukraine "On the State Border Guard Service of Ukraine") ${ }^{12}$.

The central executive body with a special status has specific tasks and credentials defined by Ukraine's Constitution and legislation, and a special procedure for the formation, reorganization, liquidation, control, accountability, appointment and dismissal of heads and resolving other issues may be established for it ${ }^{13}$.

The special mission of the SBGSU is determined, first of all, by the sphere's specificity of activity and objects of protection, which is determined by the national interests of the country and its state security: state

${ }^{10}$ Pro rishennia Radi matsionalnoi bezpeki i oboroni Ukrainy [On the decision of the National Security and Defense Council of Ukraine]. May 62015 "Pro strategiyu natsionalnoi bezpeki Ukraini [On the National Security Strategy of Ukraine]": Ukaz Prezidenta Ukraini vid 26.05.2015 No. 287/2015. URL: http://zakon3.rada.gov.ua/laws/show/287/2015 (date of request: 31.10 .2019$)$. [In Ukrainian]

${ }^{11}$ Skakun O.F. Teoria Gosudarstva i prava [State and Law Theory]: Uchebnik. Kharkov: Consum. Un-t. vnutr. del, 2000. P. 139. [In Russian]

${ }^{12}$ Pro Derzhavnu prykordonnu sluzhbu Ukrayiny [On the State Border Guard Service of Ukraine]: zakon Ukrayiny vid 03.04.2003 r. № 661-IV. Data onovlennya: 04.01.2019. URL: http://zakon.rada.gov.ua/laws/main/661-15 (date of request: 31.10.2019.[In Ukrainian]

${ }^{13}$ Administratyvne pravo Ukrayiny [Administrative Law of Ukraine] [Pidruchnyk dlya yuryd. vuziv i fak. / YU.P. Bytyak, V.V. Bohuts'kyy, V.M. Harashchuk ta in.]; Za red. YU.P. Bytyaka. Kharkiv: Pravo, 2001. p. 73. ). [In Ukrainian] 
sovereignty, constitutional order, territorial integrity, etc. Accordingly, the peculiarities of administrative and legal regulation of the managing activities of the Ukrainian state border guard bodies (units) chiefs are determined by SBU's safeguarding field's specifics, namely:

First, the tasks of the executive body responsible for safeguarding of SBU depend entirely on the state's «political regime», domestic and foreign policies. That is, the SBGSU provides political safeguarding of the $\mathrm{SBU}^{14}$, it is an instrument of implementation of Ukraine's border policy in relations with neighboring and other world countries. Ensuring reliable safeguarding of the SBU is one of the stipulations of Ukraine's national security.

Second, the proper performance of SBGSU duties depends on the legal status of SBU with the neighboring state.

Third, the SBGSU is one of the main party of safeguarding and protection of the SBU, that, according to Art. 2 of the Law of Ukraine «On the State Border Guard Service of Ukraine», in addition to other main functions, has the function of coordination military formations' activities and relevant law enforcement agencies related to the protection of the SBU, as well as the activities of state bodies exercising different control types during the crossing of the SBU or involved in procuring of the SBU regime, border regime and the SBU border crossing regime ${ }^{15}$.

Fourth, SBGSU is a professional military organization. Personnel is staffed with military and civilians. Recruitment of SBGSU by military personnel and their military service are carried out based on the Law of Ukraine «On Military Duty and Military Service», the Statutes of the Armed Forces of Ukraine, the Regulations on the military service by the relevant categories of military personnel, etc.

Military organization's (structure) peculiarity is that it is an institution where relationships are built on the principle of unity, statutory rules of relations and are provided with an increased degree of military personnel's responsibility for violating the military service's established order (military crimes) following Art. 401-435 of the Criminal Code of Ukraine, including

${ }^{14}$ Administratyvne pravo Ukrayiny [Administrative Law of Ukraine] [Pidruchnyk dlya yuryd. vuziv i fak. / YU.P. Bytyak, V.V. Bohuts'kyy, V.M. Harashchuk ta in.]; Za red. YU.P. Bytyaka. Kharkiv: Pravo, 2001. p. 471. [In Ukrainian]

${ }^{15}$ Pro Derzhavnu prykordonnu sluzhbu Ukrayiny [On the State Border Guard Service of Ukraine]: zakon Ukrayiny vid 03.04.2003 r. № 661-IV. Data onovlennya: 04.01.2019. URL: http://zakon.rada.gov.ua/laws/main/661-15 (date of request: 31.10.2019).[In Ukrainian] 
for violating the statutory rules for carrying out the border service, under Article 419 of this Code $^{16}$.

Fifth, considering the peculiarities of the official activity of the SBGSU body (unit) chief, it is necessary to take into account particular subdivision's functional assignment's peculiarities, the essence and specificity of its OSA, official task's nature.

The implementation of management depends on the specific position of the body (unit) chief in the SBGSU structure. At present, it is possible to conclude that there are four levels of management system in the SBGSU: higher, regional, middle and lower.

All chiefs of the SBGSU can be contingently divided into body chiefs and unit chiefs. The SBGSU bodies chiefs are the Head of the SBGSU, chiefs of the intelligence body, territorial bodies, Ukrainian state border guard bodies, and others. Such bodies are legal entities, have a seal with the image of the State Emblem of Ukraine and title, other seals and stamps, bank accounts, including in foreign currency. The SBGSU unit chiefs are chiefs of groups, sectors, divisions, subdivisions, departments, departments of the SBGSU bodies, as well as units of the lower level. Such units are usually structural units of bodies.

Management in a service activity is also influenced by whether direct management is exercised alone, or whether the manager has management bodies (deputies) through which he directs the activities of subordinate bodies (units) by delegating his credentials. Some of the SBGSU body chiefs may use collegial and advisory bodies in their management.

Management implementation also depends on the subordinate staff's legal status. The SBGSU personnel (staff) includes military and civilian employees of the SBGSU (hereinafter - employees). Labor relations between the SBGSU and its employees are regulated by the legislation on labor, Ukraine's public service and labor contracts (contracts), with military personnel - following the legislation on military service. This defines the content and features of personnel management in the SBGSU.

Thus, these and other peculiarities influence the content of the SBGSU bodies (units) chiefs managing activities and characterize the features of its administrative and legal regulation. The SBGSU body (unit) chief managing procedure may be regulated by the relevant legal acts or carried out at his discretion. Each chief chooses for themselves the most expedient means, techniques, methods of influencing the subordinates to convince, encourage

\footnotetext{
${ }^{16}$ Kryminal'niy kodeks Ukrayiny [Criminal Code of Ukraine]: Zakon Ukrayiny vid 05 kvitnya 2001 roku № 2341-III. Data onovlennya: 19.10.2019. URL: http://zakon3.rada.gov.ua/ laws/2341-14 (date of request: 31.10.2019).[In Ukrainian]
} 
or compel them to fulfill their assigned tasks, preferring to individual, collegial, collective, combined, administrative, moral, economic or other methods. The SBGSU body chief must know and understand his rights and responsibilities in the management. Otherwise, he is responsible for the failure to perform and negligent performance of his/her duties, including the responsibilities for managing the relevant organizational unit.

\section{The main tendencies of the administrative and legal regulation of the managing activities of the Ukrainian in modern conditions}

Among the main tendencies in the administrative and legal regulation of the SBGSU state border guard bodies (units) chiefs managing activities in the present conditions are the following.

One of the main tendencies of administrative and legal regulation is that further development of the SBGSU is determined at the level of legal acts of the President of Ukraine and the Cabinet of Ministers of Ukraine. As an example, the Concept of Development of the SBGSU for the period up to 2015, which was approved by the Decree of the President of Ukraine of 19.06.2006 No. $546 / 2006$ and the Strategy of the SBGSU, approved by the decree of the Cabinet of Ministers of Ukraine of November 23, 2015, No. 1189.

Thus, according to the Strategy of the SBGSU development, among its main tasks, along with SBU's integrated security management system creation, is the SBGSU management system modernization and improvement of interaction with other bodies that are part of the security and defense sector. The fulfillment of this task is supposed to be carried out due to:

- Management system decentralization;

- expanding SBGSU Main Service Management Center (hereinafter SMC) functional capabilities, improving its activities and organizing interaction with Ukraine Main Situational Center, the Anti-Terrorist Center at the Security Service of Ukraine and departmental situational centers;

- modern information technologies introduced into the system of management and ensuring the protection of information resources;

- providing scientific support for SBGSU development, etc ${ }^{17}$.

Another trend of administrative and legal regulation is the annual determination of the directions of further development of the SBGSU for the calendar year, which is endorsed by the decisions of the SBGSU Board and approved by the Interior Minister.

\footnotetext{
${ }^{17}$ Pro skhvalennya Stratehiyi rozvytku Derzhavnoyi prykordonnoyi sluzhby [On approval of the Strategy for the SBGSU development]: rozporyadzhennya Kabinetu Ministriv Ukrayiny vid 23 lystopada 2015 roku № 1189-r. URL: http://zakon3.rada.gov.ua/laws/show/1189-2015-r (date of request: 31.10 .2019$)$.[In Ukrainian]
} 
So, for example, according to the Main directions of activity and SBGSU further development in 2017, it was supposed:

- to ensure the unification and up-to-date maintenance of information and analytical materials in the SBGSU in the areas of activity at all levels of management;

- to ensure the modern system formation for managing the forces and means of the Maritime Guard of the SBGSU;

- to provide further development of service management automation processes and response to situations, application of innovations in the refinement of SMC as modern control points, increase of their technical capabilities for automated situation monitoring and control over the use of forces and means;

- to ensure the permanent operative staff readiness to perform management tasks at suburban, reserve control points, to bring into compliance with the regulatory documents requirements of the suburban reserve control point operation and a mobile control point of the SBGSU Administration;

- to continue to increase the service management system's effectiveness, to respond promptly to the situation changes in the special period conditions;

- to transform EU and NATO international experience into a personnel management system;

- to improve the staff motivation system, etc ${ }^{18}$.

In accordance with the Main Activities Directions and Further Development of the SBGSU in 2018, it was envisaged to reform the structure management system and number of the SBGSU by optimization of the Border Guard Departments, deployment of Border Inspectorate Departments and Border Control; reforming of the verticals of regional administrations and border squads; bringing the ratio of the organizational structures of SBU safeguarding bodies to the indicator: $75 \%$ - border guard units, $25 \%$ - the management and logistics units; optimization of separate units of the central subordination, etc. ${ }^{19}$

${ }^{18}$ Osnovni napryamy diyal'nosti ta podal'shoho rozvytku Derzhavnoyi prykordonnoyi sluzhby Ukrayiny u 2017 rotsi [Main directions of activity and further development of the SBGS of Ukraine in 2017]: Derzhavna prykordonna sluzhba Ukrayiny, ofitsiynyy sayt. URL: https://dpsu.gov.ua/ua/-osnovni-napryami-diyalnosti-ta-podalshogo-rozvitku-derzhavnoiprikordonnoi-sluzhbi-ukraini/ (date of request: 26.12.2018).[In Ukrainian]

${ }^{19}$ Osnovni napryamy diyal'nosti ta podal'shoho rozvytku Derzhavnoyi prykordonnoyi sluzhby Ukrayiny u 2018 rotsi [Main directions of activity and further development of the SBGS of Ukraine in 2018]: Prykordonnyk Ukrayiny. Hazeta Derzhavnoyi prykordonnoyi sluzhby Ukrayiny, № 3-4 (5593-5594), 26 sichnya 2018 roku. p. 12-15. [In Ukrainian] 
In the Main Activities Directions and Further Development of the SBGSU in 2019, the issues of improvement of management system and structure, the SBGSU chiefs of bodies (units) managing activities are not given enough attention ${ }^{20}$.

Accordingly, among the main tendencies of the administrative and legal regulation of the past years, which negatively affected the quality of the tasks assigned to the SBGSU on safeguarding of the SBU, was its focus on ensuring the managing activities of the heads of the highest management bodies of the SBGSU, which negatively affected the situation of ensuring border guard activities of the SBGSU bodies (units). As a result, certain disparities in the correlation between the lead units of the SBGSU and the number of personnel involved in the border guard activities were observed.

Regarding the total number of personnel of the SBGSU, as of August 1, 1991, the number of Border troops of Ukraine was 16800 military and civilian employees. Subsequently, this figure increased and as of December 30, 2004, was to be 50,000 (of which 47,000 were military). After the creation of the SBGSU, the Law of Ukraine «On the State Border Guard Service of Ukraine» of April 3, 2003 (came into force on August 1, 2003), taking into account personnel existing number, it was also envisaged to increase it gradually by 5000 every year during 2004-2005 and bringing it to 50,000 as of January 1, 2005 (42,000 of the military). Under the Law of Ukraine «On Amendments to Article 6 of the Law of Ukraine» On the State Border Guard Service of Ukraine «of April 9, 2015, No. 306-VIII, the SBGSU of Ukraine increased by 3000 and the number of its personnel was determined in 53000 persons (45000 of the military personnel).

Considering the length of the SBU, which is $6992,982 \mathrm{~km}$ (of which land $-5637,982 \mathrm{~km}$, the maritime border $-1355,0 \mathrm{~km}$, the exclusive (maritime) economic zone - 72658 square kilometers. With the CIS states $4601,24 \mathrm{~km}$, with the EU member states $-1390,742 \mathrm{~km}$. The territorial sea - $1001 \mathrm{~km})^{21}$, then for $1 \mathrm{~km}$ of SBU out of 45,000 there were more than 6 military employees (provided that all of them are involved in the safeguarding of the SBU). But practice shows that this figure was much lower.

Back in 2016, Secretary of the Interior of Ukraine Arsen Avakov declared the idea of reducing the number of generals in the structures, which

\footnotetext{
${ }^{20}$ Osnovni napryamy diyal'nosti ta podal'shoho rozvytku DPS Ukrayiny u 2019 rotsi [Main directions of activity and further development of the SBGSU in 2019]. https://dpsu.gov.ua/upload/Naprjami_DPSU_Optimized (date of request: 31.10.2019).[In Ukrainian]

${ }^{21}$ Osnovni napryamy diyal'nosti ta podal'shoho rozvytku DPS Ukrayiny u 2019 rotsi [Main directions of activity and further development of the SBGSU in 2019]. https://dpsu.gov.ua/upload/Naprjami_DPSU_Optimized (date of request: 31.10.2019).[In Ukrainian]
} 
are subordinate to his agency. The Facebook page stated that on behalf of the President of Ukraine he submitted for approval a draft of the reduction of general's positions. It was proposed that the staff of general's positions and ranks in the SBGSU (with some about 42 thousand people) should be reduced from 74 to $14^{22}$. However, for the period from 2016 to 2019 , only 20 such positions were cut in the SBGSU. Information about the number of general's positions was in the interview with the Head of the SBGSU. "There were 54 general's positions in the SBGSU. At the time of my appointment to the post, 38 people held the rank of General. After the administrative reform, we cut 6 general positions. And at the end of the reform, we have only 19 generals left," S. Deineko said ${ }^{23}$.

For this purpose, a set of measures is being implemented to optimize the management levels and units of the structure of the SBGSU and eliminate unnecessary ones. So, today, the SBGSU Administration structure has been reformed, and 4 of 8 regional branches of the SBGSU have been liquidated. According to the Head of the SBGSU S. Deyneko: "Service reform is necessary from the top down. If once there were 3 regional offices until 2001, now the structure contains 8 offices. We want to save 4 regional offices in the Service, and then completely abandon them. We want to bring the SBGSU to European analogs». He cited the example of Poland, where a three-level system of management exists - the units that directly guard the border, then the border unit and the Warsaw-based administration. There is a similar structure in the US; they do not have any regional leaders ${ }^{24}$.

The main tendencies of administrative and legal regulation of managing activities should also include repeated changes in the issues of appointment of the senior leadership of the SBGSU and the distribution of relevant credentials among the higher officials of the state.

The Head of the State Committee for Ukrainian state border guard Commander of the Border Guard of Ukraine, at some time was appointed and dismissed by the President of Ukraine. It was also determined concerning the Head of the SBGSU, the appointment and dismissal of which was made by the President of Ukraine. Then the appointment of the

\footnotetext{
${ }^{22}$ Povidomlennya na ofitsiyniy storintsi facebook Ministra vnutrishnikh sprav Ukrayiny Arsena Avakova [The announcement on the official facebook page of the Secretary of the Interior of Ukraine Arsen Avakov]. URL: https://www.facebook.com/arsen.avakov.1/posts/ 1108372932586145?pnref=story (date of request: 27.10.2019) [In Ukrainian]

${ }^{23}$ Interv'yu Holovy DPS Ukrayiny [Interview with the Chairman of the SBGSU]. URL: https://www.ukrinform.ua/rubric-ato/2796747-kilkist-generaliv-u-derzprikordonsluzbi-skorotatudvici-dejneko.html (date of request: 27.10.2019) [In Ukrainian]

${ }^{24}$ Interv'yu Holovy DPS Ukrayiny [Interview with the Chairman of the SBGSU]. URL: https://www.blackseanews.net/read/156590 (date of request: 27.10.2019) [In Ukrainian]
} 
President of Ukraine was envisaged on the submission of the Prime Minister of Ukraine.

Under paragraph 10 of the current Regulation on the Administration of the SBGSU, the Head of the SBGSU is appointed to the post and dismissed by the Cabinet of Ministers of Ukraine upon the submission of the Prime Minister of Ukraine, submitted based on proposals of the Secretary of the Interior. The SBGSU Head has two deputies, including the first deputy, who are appointed and dismissed by the Cabinet of Ministers of Ukraine on the proposal of the Prime Minister of Ukraine, submitted based on proposals of the Secretary of the Interior ${ }^{25}$.

The content norms of this Regulation are in contradiction with the requirements of Article 8 of the Law of Ukraine "On the State Border Guard Service of Ukraine", second part of which states that the Head of the SBGSU is appointed by the President of Ukraine upon the submission of the Prime Minister of Ukraine and suspends his credentials on this position. The Head of the SBGSU has deputies who are appointed by the President of Ukraine upon SBGSU Head's submission ${ }^{26}$.

The Decree of the President of Ukraine dated October 25, 2019 №774 / 2019 lists the positions of military formations heads, law enforcement agencies, candidates for appointment to which agrees with the President of Ukraine on the SBGSU: SBGSU Administration departments' directors; SBGSU regional departments chiefs; rector of the National Academy of SBGSU named after B. Khmelnitsky ${ }^{27}$. To avoid different approaches to these issues, there is a need for such coordination, etc.

According to the results of past studies, the structural level of the SBGSU, which officials use the most managing methods, according to the respondents, are Ukrainian state border guard bodies and the Maritime Guard Bodies (77.7\%), and the effectiveness of service activities management depends on border guard bodies chiefs $(66.6 \%)$ and border guard units chiefs $(51.1 \%)$ and the SBGSU Maritime Guard Bodies. The

\footnotetext{
${ }^{25}$ Pro zatverdzhennya Polozhennya pro Administratsiyu Derzhavnoyi prykordonnoyi sluzhby Ukrayiny [On Approval of the Regulation on the Administration of the State Border Guard Service of Ukraine]: Postanova Kabinetu Ministriv Ukrayiny vid 16 zhovtnya 2014 r. № 533. Data onovlennya: 07.08.2015. URL: http://zakon2.rada.gov.ua/laws/show/533-2014-p (date of request: 31.10.2019) [In Ukrainian]

${ }^{26}$ Pro Derzhavnu prykordonnu sluzhbu Ukrayiny [On the State Border Guard Service of Ukraine]: zakon Ukrayiny vid 03.04.2003 r. № 661-IV. Data onovlennya: 04.01.2019. URL: http://zakon.rada.gov.ua/laws/main/661-15 (date of request: 31.10.2019).[In Ukrainian]

${ }^{27}$ Pro vnesennia zmin do Ukazu Prezidenta vid 4 chervnia 2008 roku №516 [On Amendments to the Presidential Decree of June 4, 2008 No. 516]: Ukaz Prezidenta Ukrainy vid 25 zhovtnia 2019 №774/2019 URL: https://www.president.gov.ua/documents/7742019-30077 ((date of request: 27.10.2019) [In Ukrainian]
} 
main reason, which hinders the organization of effective management of the official activities the SBGSU bodies (units), is the imperfection of the legislation on the SBU $(57.8 \%)^{28}$.

The elimination of the relevant shortcomings and contradictions should be a priority in the administrative and legal regulation of managing activities.

There are many other problematic issues that are caused by the state of administrative and legal regulation of the Ukrainian border guard bodies (units) activities in the current conditions: lower-level bodies' (units) incompleteness, staff turnover, lack of a clear promotion program, low level of border guard bodies (units) motivation, etc. All of them need to be resolved, including by amending Ukraine's current legislation, improving management.

\section{CONCLUSION}

Thus, the administrative and legal regulation of the managing activities of the SBGSU bodies (units) chiefs is of great importance and consists of a set of legal acts that proclaim legal norms, regulate managing activities, and determine the content of public relations between subjects and objects of management. Such regulation is carried out at the level of Ukraine's laws and by-laws, which can be divided into the following groups: the Constitution and the laws of Ukraine; resolutions of the Verkhovna Rada of Ukraine; Decrees and Orders of the President of Ukraine; resolutions and orders of the Cabinet of Ministers of Ukraine; orders of the Ministry of Interior and the SBGSU Administration, orders of the SBGSU managing bodies.

In such hierarchical structures as the SBGSU, built on the principle of unity, administrative and legal regulation of chiefs' managing activities is of particular importance. The chief is an official - a staff member appointed to a certain position, determined by the structure and staff list of the SBGSU body, entrusted with a set of official credentials for the implementation of organizational, advisory or administrative functions, as well as certain credentials concerning subordinates to make management decisions and their implementation.

At present, the specification of the essence and the establishment of clear procedural rules of management are mainly carried out not at Ukraine's laws

\footnotetext{
${ }^{28}$ Polovnikov V.V. Problemni pitannia ta shliahi udoskonalennia kerivnikami organiv (pidrozdiliv) DPS Ukrainy metodiv upravlinnia [Problematic Issues and Ways to Improve Management Methods of Heads of Bodies (Units) of the SBGS of Ukraine]: Visnik NADPSU. Seria: Uridichni nauki 2018. Vip.4 URL: http://nbuv.gov.ua/UJRN/vnadpcurn_2018_4_6
} 
level but by-laws level. This does not fully comply with the principle of legal certainty.

\section{SUMMARY}

One of the important components of Ukraine legal system reform is the improvement of administrative and legal regulation of the SBGU state border guard bodies (units) chiefs' managing activities. Only that system of management is effective, which is constantly evolving and refined based on the use of accumulated experience, improvement of its legal regulation. Some peculiarities and problematic issues of management activities are characteristic not only for the SBGSU but also for other Ukrainian law enforcement agencies and military formations.

Improvement of administrative and legal regulation of managing activities and implementation in practice of the legal certainty principle is possible in case of clear definition and specification of the managing activities procedures, not at the by-laws level, but at the level of Ukraine's laws.

The SBGSU body chief must know and understand his rights and responsibilities in the management. It concerns his tasks, duties and rights to manage the relevant organizational and structural unit. Otherwise, he may be a subject to disciplinary, administrative, criminal and other legal liability for failure to perform or negligent performances of his duties.

The enlightened provisions provide the basis for further research into these issues, the development of theoretical and practical foundations for the management implementation, improvement of Ukraine's current legislation.

\section{REFERENCES}

1. Konstitutsia Ukrayini: zakon Ukrayini № 254к/96-VR [Constitution of Ukraine]. 28 June 1996. Data onovlennia: 21.02.2019. URL: http://zakon2.rada.gov.ua/laws/main/254к/96-вp (date of request: 31.10.2019). [In Ukrainian]

2. Rishenniya Konstitutsiynogo sudu Ukrainy №. 17-rp / 2010 [Judgment of the Constitutional Court of Ukraine]. 29 June 2010. URL: https://zakon.rada.gov.ua/laws/show/v017p710-10 (date of request: 31.10.2019). [In Ukrainian]

3. Yuridichna Ensiklopediya [Legal Encyclopedia] / red. Y.S.Shemshuchenko [ta insh.] / NAN Ukrainy, V.M. Koretsky Institut derzavi i prava. Kyiv: vid. Ukrainska entsiklopediya im. M.P. Bazhana, Toml. 3: K-M. 2001. P. 617. [In Ukrainian] 
4. Babosov, E. M. Sotsyolohyya upravleniya : posobye dlya studentov vuzov [Sociology of management] / E. M. Babosov. 6-e izd., pererab. y dop. Mynsk : TetraSystems, 2010. S. 3-4.[In Ukrainian]

5. Velykyy tlumachniy slovnyk suchasnoyi ukrayins'koyi movy [The Big Interpretive Dictionary of Modern Ukrainian] / Uklad. i holov. red. V. T. Busel. Kyiv; Irpin': VTF «Perun», 2009. S. 1511. [In Ukrainian]

6. Noviy tlumachniy slovnyk ukrayins'koyi movy : u 3 t. 200000 sliv [New interpretative dictionary of the Ukrainian language] / [uklad. Vasyl' Yaremenko, Oksana Slipushko]. vyd. 2-e, vypr., t. 3 P-YA. Kyiv : AKONIT, 2008. S. 624-625. [In Ukrainian]

7. Yuridichna Ensiklopediya [Legal Encyclopedia] / red. Y.S.Shemshuchenko [ta insh.] / NAN Ukrainy, V.M. Koretsky Institut derzavi i prava. Kyiv: vid. Ukrainska enciklopedia im.r M.P. Bazhan, Tom.T. 6: T-Y. 2004, p. 768. [In Ukrainian]

8. Pro rishennia Radi matsionalnoi bezpeki i oboroni Ukrainy [On the decision of the National Security and Defense Council of Ukraine]. 6 May 2015 "Pro strategiyu natsionalnoi bezpeki Ukraini [On the National Security Strategy of Ukraine]": Ukaz Prezidenta Ukraini vid 26.05.2015 No. 287/2015. URL: http://zakon3.rada.gov.ua/laws/show/287/2015 (date of request: 31.10.2019). [In Ukrainian]

9. Skakun O.F. Teoria Gosudarstva i prava [State and Law Theory]: Uchebnik. Kharkov: Consum. Un-t. vnutr. del, 2000. p. 704 [In Russian]

10. Pro Derzhavnu prykordonnu sluzhbu Ukrayiny [On the State Border Guard Service of Ukraine]: zakon Ukrayiny vid 03.04.2003 r. № 661-IV. Data onovlennya: 04.01.2019. URL: http://zakon.rada.gov.ua/laws/ main/661-15 (date of request: 31.10.2019. [In Ukrainian]

11. Administratyvne pravo Ukrayiny [Administrative Law of Ukraine] [Pidruchnyk dlya yuryd. vuziv i fak. / YU.P. Bytyak, V.V. Bohuts'kyy, V.M. Harashchuk ta in.]; Za red. YU.P. Bytyaka. Kharkiv: Pravo, 2001. p. 73.). [In Ukrainian]

12. Kryminal'niy kodeks Ukrayiny [Criminal Code of Ukraine]: Zakon Ukrayiny vid 05 kvitnya 2001 roku № 2341-III. Data onovlennya: 19.10.2019. URL: http://zakon3.rada.gov.ua/laws/2341-14 (date of request: 31.10.2019).[In Ukrainian]

13. Pro skhvalennya Stratehiyi rozvytku Derzhavnoyi prykordonnoyi sluzhby [On approval of the Strategy for the SBGSU development]: rozporyadzhennya Kabinetu Ministriv Ukrayiny vid 23 lystopada 2015 roku № 1189-r. URL: http://zakon3.rada.gov.ua/laws/show/1189-2015-r (date of request: 31.10 .2019$)$.[In Ukrainian] 
14. Osnovni napryamy diyal'nosti ta podal'shoho rozvytku Derzhavnoyi prykordonnoyi sluzhby Ukrayiny u 2017 rotsi [Main directions of activity and further development of the SBGSU in 2017]: Derzhavna prykordonna sluzhba Ukrayiny, ofitsiynyy sayt. URL: https://dpsu.gov.ua/ua/-osnovni-napryami-diyalnosti-ta-podalshogo-

rozvitku-derzhavnoi-prikordonnoi-sluzhbi-ukraini/ (date of request: 26.12.2018).[In Ukrainian]

15. Osnovni napryamy diyal'nosti ta podal'shoho rozvytku Derzhavnoyi prykordonnoyi sluzhby Ukrayiny u 2018 rotsi [Main directions of activity and further development of the SBGSU in 2018]: Prykordonnyk Ukrayiny. Hazeta Derzhavnoyi prykordonnoyi sluzhby Ukrayiny, № 3-4 (5593-5594), 26 January 2018 p. 12-15. [In Ukrainian]

16. Osnovni napryamy diyal'nosti ta podal'shoho rozvytku DPS Ukrayiny u 2019 rotsi [Main directions of activity and further development of the SBGSU in 2019]. https://dpsu.gov.ua/upload/Naprjami_DPSU_ Optimized (date of request: 31.10.2019).[In Ukrainian]

17. Povidomlennya na ofitsiyniy storintsi facebook Ministra vnutrishnikh sprav Ukrayiny Arsena Avakova [The announcement on the official facebook page of the Secretary of the Interior of Ukraine Arsen Avakov]. URL: https://www.facebook.com/arsen.avakov.1/posts/ 1108372932586145?pnref=story (date of request: 27.10.2019) [In Ukrainian]

18. Interv'yu Holovy DPS Ukrayiny [Interview with the Chairman of the SBGSU]. URL: https://www.ukrinform.ua/rubric-ato/2796747-kilkistgeneraliv-u-derzprikordonsluzbi-skorotat-udvici-dejneko.html (date of request: 27.10.2019) [In Ukrainian]

19. Interv'yu Holovy DPS Ukrayiny [Interview with the Chairman of the SBGSU]. URL: https://www.blackseanews.net/read/156590 (date of request: 27.10.2019) [In Ukrainian]

20. Pro zatverdzhennya Polozhennya pro Administratsiyu Derzhavnoyi prykordonnoyi sluzhby Ukrayiny [On Approval of the Regulation on the Administration of the State Border Guard Service of Ukraine]: Postanova Kabinetu Ministriv Ukrayiny vid 16 zhovtnya 2014 r. № 533. Data onovlennya: 07.08.2015. URL: http://zakon2.rada.gov.ua/ laws/show/533-2014-p (date of request: 31.10.2019) [In Ukrainian]

21. Pro vnesennia zmin do Ukazu Prezidenta vid 4 chervnia 2008 roku №516 [On Amendments to the Presidential Decree of June 4, 2008 No. 516]: Ukaz Prezidenta Ukrainy vid 25 zovtnia 2019 №774/2019 URL: https://www.president.gov.ua/documents/7742019-30077 (date of request: 27.10.2019) [In Ukrainian] 
22. Polovnikov V.V. Problemni pitannia ta shliahi udoskonalennia kerivnikami organiv (pidrozdiliv) DPS Ukrainy metodiv upravlinnia [Problematic Issues and Ways to Improve Management Methods of the SBGSU Heads of Bodies (Units)]: Visnik NADPSU. Seria: Uridichni nauki 2018. Vip.4 URL: http://nbuv.gov.ua/UJRN/vnadpcurn_2018_4_6.

\section{Information about the author:} Vadym Polovnikov,

Candidate of Juridical Sciences, Associate Professor, Department of Operative and Investigative Activity Management National Academy of State Border Guard Service of Ukraine named after Bohdan Khmelnytskyi Khmelnytskyi city, st. Shevchenko 46 ORCID ID: orcid.org/0000-0002-8054-909X 